\title{
XANTHINE OXIDASE INHIBITORY ACTIVITY OF RHUS MYSORENSIS LEAVES
}

\section{VIVEKANANDAN K ${ }^{1}$, BHAVYA E ${ }^{2 *}$, STALIN $C^{3}$, LAKSHMI PRASANNA T ${ }^{3}$}

${ }^{1}$ Department of Pharmacy Practice, Faculty of Pharmacy, Dr. M.G.R. Educational and Research Institute, Deemed to be University, Madurvoyal, Chennai, India. ${ }^{2}$ Department of Pharmacy Practice, School of Pharmaceutical Sciences, Vels Institute of Science Technology and Advanced Studies, Chennai, India. ${ }^{3}$ Patient Safety Pharmacovigilance Associate, Pharmacovigilance Programme of India (PvPI), Indian Pharmacopoeia Commission, Ghaziabad, India. Email: bhavyaekambaram@yahoo.com

Received: 10 October 2018, Revised and Accepted: 11 December 2018

\section{ABSTRACT}

Objective: The objective of this study was to assess the in vitro xanthine oxidase (XO) inhibiting activity of the methanolic leaf extract of the Rhusmysorensis

Methods: Uric acid is synthesized in the presence of XO which is an essential enzyme. Various concentrations of the leaf extract were taken. XO inhibiting activity was spectrophotometrically assayed. By increasing absorbance at $295 \mathrm{~nm}$, the degree of enzyme spontaneity was determined.

Results: Inhibition concentration 50 (IC50) of the methanolic extract of $R$. mysorensis leaves was $45.24 \pm 0.34 \mu \mathrm{g} / \mathrm{ml}$, compared with IC50 value of the standard allopurinol of $7.8 \pm 1.28 \mu \mathrm{g} / \mathrm{ml}$.

Conclusion: Methanol extract of R. mysorensis can be used to treat hyperuricemia and gout after proper preclinical and clinical studies.

Keywords: Rhus mysorensis, Inhibitory effect, Gout, Hyperuricemia, Xanthine oxidase.

(C) 2018 The Authors. Published by Innovare Academic Sciences Pvt Ltd. This is an open access article under the CC BY license (http://creativecommons. org/licenses/by/4. 0/) DOI: http://dx.doi.org/10.22159/ajpcr.2018.v11i4.31737

\section{INTRODUCTION}

Gout is a known metabolic disorder distressing humans and its morbidity is present keeping on growing over the past years. The gout prevalence is diagnosed by increased level of uric acid that accumulates in joints and kidneys, causing gouty arthritis and nephrolithiasis [1,2]. An enzyme xanthine oxidase (XO) which catalyzes the hydroxylation of hypoxanthine which converts xanthine into uric acid. Then, the uric acid is excreted by kidneys. Production of excessive otherwise uric acid elimination is decreased which results into hyperuricemia [3]. The drugs used for this purpose are uricosurics and uricostatics. Uricosuric drugs work by inhibiting the absorption of uric acid in the kidney tubules, whereas uricostatic drug inhibits XO enzyme which converts hypoxanthine into xanthine and it is converted into uric acid, thereby decreases the production of uric acid. The World Health Organization reveals that medicinal plants would be the best source of drugs. Before using it in humans every plants should be investigated for its safety and efficacy.

R. mysorensis belonging to the family of Anacardiaceae is a shrub with thorny branches found in hot dry places and stony regions in India. Reports suggest that the plant contains alkaloids, glycosides, flavonoids, saponins, tannins, sterols, phenols, amino acids, and protein. Earlier studies of the plant claim that it has potential hepatoprotective, antimicrobial, antiurolithiatic, antidiabetic, hypolipidemic, and antioxidant activities. Folk usage of the plant suggested that its use in diabetes, antifertility, psoriasis, and diarrhea problems [4]. However there is no relavant study about inhibiting activity of xanthine oxidase of $R$. mysorensis. Hence, the inhibitory activity for XO in this study was analyzed using methanolic extract of the leaves of $R$. mysorensis.

\section{MATERIALS AND METHODS}

\section{Plant material collection}

The whole plant $R$. mysorensis was collected from hilly Tirupati region, Andhra Pradesh. Authentication for the plant is done by Dr. Madhav Chetty. K, Department of Botany, Sri Venkateswara University, Tirupati.
Extraction of plant material

Leaves were removed and air dried under shade, powdered and it was stored in an airtight container. Weigh $500 \mathrm{~g}$ of the powdered material was extracted with methanol $(80 \%)$ by the process of soxhlation. The filtrate was concentrated at reduced pressure by rotary flash vacuum evaporator [5].

\section{Drugs and chemicals}

XO, xanthine, and allopurinol were obtained from HiMedia Labs, Mumbai, India. The drugs and chemicals used for this study were acquired with commercial and diagnostic category.

\section{XO Inhibiting (XOI) activity [6]}

Inhibiting activity of $\mathrm{XO}$ was spectrophotometrically assayed in aerobic environments by means of substrate - xanthine. The standard drug allopurinol $(1 \mathrm{mg} / \mathrm{ml})$ and the extract were prepared by dissolving in dimethyl sulfoxide initially (not $>5 \%$ of total volume) and then made up to the required volume using potassium dihydrogen phosphate buffer with $\mathrm{pH}$ of 7.5. Then, assay mixture consisting $1 \mathrm{ml}$ of extract at different concentrations (5-100 $\mu \mathrm{g} / \mathrm{ml}), 2.9 \mathrm{ml}$ potassium dihydrogen phosphate buffer with $\mathrm{pH}$ of 7.5 , and $0.1 \mathrm{ml} \mathrm{XO}$ enzyme solution $(0.1 \mathrm{U} / \mathrm{ml}$ in potassium dihydrogen phosphate buffer at $\mathrm{pH}$ of 7.5 is prepared instantly previous to work). After preincubation for $15 \mathrm{~min}$ at about $25^{\circ} \mathrm{C}, 2 \mathrm{ml}$ of substrate solution was added to initiate the reaction. The assay mixture was incubated at $25^{\circ} \mathrm{C}$ for $30 \mathrm{~min}$, by the addition of $1 \mathrm{~N}$ $\mathrm{HCl}$, the reaction was then stopped. At $290 \mathrm{~nm}$, absorbance is measured against blank. Allopurinol (5-100 $\mathrm{gg} / \mathrm{ml})$, recognized inhibitor of XO, is selected as a positive control. XO 1 unit is the quantity needed to yield $1 \mathrm{mmol}$ of uric acid per minute by $25^{\circ} \mathrm{C}[6,7]$. XO inhibiting activity was calculated as percentage inhibition as given below.

Percentage inhibition $=\{(\mathrm{A}-\mathrm{B})-(\mathrm{C}-\mathrm{D}) /(\mathrm{A}-\mathrm{B})\} \times 100$

Here, A - is the enzyme activity without fraction, $\mathrm{B}$ - is the control for A without fraction and enzyme, $\mathrm{C}$ and D were the fraction activity with or without XO. 
Table 1: In vitro XO inhibitory activity of $R$. mysorensis leaves

\begin{tabular}{|c|c|c|c|c|c|c|}
\hline \multirow[t]{2}{*}{ Drugs } & \multicolumn{5}{|c|}{ Percentage XO inhibition } & \multirow[t]{2}{*}{$\mathrm{IC}_{50}(\mu \mathrm{g} / \mathrm{ml})$} \\
\hline & $5 \mu \mathrm{g} / \mathrm{ml}$ & $10 \mu \mathrm{g} / \mathrm{ml}$ & $25 \mu \mathrm{g} / \mathrm{ml}$ & $50 \mu \mathrm{g} / \mathrm{ml}$ & $100 \mu \mathrm{g} / \mathrm{ml}$ & \\
\hline R. mysorensis leaves extract & $27.54 \pm 0.96$ & $33.71 \pm 0.29$ & $41.25 \pm 0.53$ & $51.44 \pm 0.89$ & $63.52 \pm 0.64$ & $45.24 \pm 0.34$ \\
\hline
\end{tabular}

Values are mean \pm SEM of three parallel measurements, $R$. mysorensis: Rhus mysorensis, XO: Xanthine oxidase

In triplicates, the assay is made and the values for inhibition concentration 50 (IC50) were calculated based on the inhibitory activity.

\section{RESULTS AND DISCUSSION}

The present study is conducted to examine XO inhibiting activity for $R$. mysorensis leaf extract that might have the perspective to treat increased amount of uric acid and gout. The synthesis of uric acid by the conversion of hypoxanthine into xanthine, the oxidative pathway which occurs in the presence of enzymes XO and guanase, continued with uric acid oxidized from xanthine which is catalyzed by XO. Inhibiting the XO is thus very essential and necessary as pharmacological interference for gout and hyperuricemia [7].

Various concentrations of the leaf extract were taken and XOI activity was assayed by spectrophotometrically. The enzyme inhibitory activity was calculated by raising the absorbance to about $295 \mathrm{~nm}$. The IC50 of the methanolic extract of $R$. mysorensis leaves was $45.24 \pm 0.34 \mu \mathrm{g} / \mathrm{ml}$, compared with IC50 value of the standard allopurinol of $7.8 \pm 1.28 \mu \mathrm{g} / \mathrm{ml}$. The results are given in Table 1 .

\section{CONCLUSION}

We concluded that the methanolic extract of $R$. Mysorensis leaves processes and having a good XO inhibiting activity, thereby it has the bioactive elements helpful for the management of diseases occurred by $\mathrm{XO}$. Hence, further in future, it is necessary to make studies on isolation of biologically active substances those effects with XO inhibiting activity.

\section{CONFLICTS OF INTEREST}

All the authors declared that this research work does not have any conflicts of interest.

\section{REFERENCES}

1. B-Rao C, Kulkarni-Almeida A, Katkar KV, Khanna S, Ghosh U, Keche A, et al. Identification of novel isocytosine derivatives as xanthine oxidase inhibitors from a set of virtual screening hits. Bioorg Med Chem 2012;20:2930-9.

2. Flemmig J, Kuchta K, Arnhold J, Rauwald HW. Olea europaea leaf (Ph.Eur.) extract as well as several of its isolated phenolics inhibit the gout-related enzyme xanthine oxidase. Phytomedicine 2011;18:561-6.

3. Lespade L, Bercion S. Theoretical study of the mechanism of inhibition of xanthine oxidase by flavonoids and gallic acid derivatives. J Phys Chem B 2010;114:921-8.

4. Swathi H, Shekshavali T, Kuppast IJ, Ravi MC, Priyanka R. A review on Rhus mysorensis. Pharm Innov J 2015;4:94-6.

5. Khandelwal KR. Practical Pharmacognosy. Vol. 11. Pune: Nirali Prakashan; 2005. p. 149-53.

6. Muthiah PL. In vitro xanthine oxidase inhibitory activity of leaves, fruits and peel extracts of Citrus aurantium, Citrus limetta and Citrus limon. Int J Phytopharm 2012;2:77-80.

7. Dipiro JT, Talbert RL, Yee GC, Matzke G, Wells B, Posey LM. Pharmacotherapy: A Patophysiologic Approach. $7^{\text {th }}$ ed. New York: McGraw Hill; 2008 